Relations industrielles

Industrial Relations

\title{
Structural Reforms in Enterprise
}

\section{Perreault}

Volume 5, numéro 2, novembre 1949

URI : https://id.erudit.org/iderudit/1023291ar

DOI : https://doi.org/10.7202/1023291ar

Aller au sommaire du numéro

Éditeur(s)

Département des relations industrielles de l'Université Laval

ISSN

0034-379X (imprimé)

1703-8138 (numérique)

Découvrir la revue

Citer cet article

Perreault, L. (1949). Structural Reforms in Enterprise. Relations industrielles / Industrial Relations, 5(2), 20-20. https://doi.org/10.7202/1023291ar

Tous droits réservés (C Département des relations industrielles de l’Université Laval, 1949
Ce document est protégé par la loi sur le droit d'auteur. L'utilisation des services d'Érudit (y compris la reproduction) est assujettie à sa politique d'utilisation que vous pouvez consulter en ligne.

https://apropos.erudit.org/fr/usagers/politique-dutilisation/ 


\section{STRUCTURAL REFORMS IN ENTERPRISE}

If my spare time had permitted it I would long ago have spoken to you on the criticisms which Monsieur Angers addressed to you in \& L'Actualité Economique $\rrbracket^{1}$ on the subject of « Reform of Structure in the Enterprise ». I find there at the same time everything necessary to condemn you and everything necessary to justify you. The reforms which he proposes at the end will meet, I am sure, with your approbation. What is still surer is that our capitalism would come out of it tolerably disfigured and that, in short, it would ressemble strangely that which you contemplated attaining by the reform of structure in the enterprise. Because your reform of the enterprise supposes a complete reversal of our capitalism. And finally, we rejoice to see sociologists and theologians bring to bear their study and their action on that precise and concrete point where capitalism works its ravages: the Enterprise. Because, thanks to the privileged legal bounds with which it is permitted to surround itself, the enterprise in its large units at least, can practise within the shelter of the law, usury, swindling and graft.

What astonishes me is to hear «conditional monopoly s spoken of by a competent economist who claims to have his feet planted on the solid earth of Canadian economy, while we bow more than ever under the yoke of economic concentration and the dictatorship which springs from it. Because it cannot be denied that by the help of the war, concentration has been accentuated and monopoly has consolidated its position. Monsieur Anger's « good child 》 capitalism is long ago out-grown. It has cut several sets of teeth and has eaten away steadily at the little and medium enterprises found in its way, while waiting to devour or to render neutral those which remain to us.

It makes us laugh to-day to hear of the risks taken by capitalist enter-

(1) L'Actualité économique, August-September 1949. prise. It is not of to-day that Monsieur Minville said that our economic system would lead to the socialization of losses and the individualization of profits. I would very much like to be shown a monopoly (for it is monopolies which here concern us seeing that they dominate the economy) which has sacrificed its profits to the service of society. During the War in Quebec, we saw an enterprise, deeply engaged in the «crusade for Christianty», grant itself 70 millions speeded-up depreciation on an increase of assets of ninety millions. What a risk! Cartels, with a view of avoiding all competition, prohibited the entry of competitors into their domain thus retarding production, and automatically prolonging the war and the massacre. Which won out: service or interest? Things would perhaps have been different if the workers, through their representatives, had had their say in the enterprises. Nothing truer than the words of Monsieur Portier: « To-day's crisis in capitalism is too often due to its efforts to maintain the advantages claimed in the name of risk by attempting to surround itself with legal safe-guards which will avoid the consequences of that risk $\gg .^{2}$ Most of the time the only risk it takes is that of making profits. Furthermore, when in the space of one generation, an economic system and its institutions has brought us to two wars, and such wars, without neglecting to prepare us another; and between the two wars, thirty millions of unemployed in the world, then the destruction of wealth, in the face of misery, to safe-guard profits - then its case, for me at least, is definitly settled whatever the risks it may assume and the services it thinks to render us!

The reforms which you advocate in enterprise present the eternal problem of ownership. We are concerned with knowing whether we should resign ourselves to a regime

(2) Chronique sociale de France, July-August 1948, p. 295. of absolute ownership or evolve towards a regime of conditional ownership or again find a middle way between ownership without work and work without ownership. This is a crucial problem to which Catholics have the duty of bringing a solution. On it depends economic equilibrium and social peace. It does not appertain only to the adversaries of the Church to give proof of their courage and even audacity by the presentation of formulas applicable to the solution of our economic and social problems. On this point it seems to me that the employers have to-day a difficult task to perform. If they chose the way of employership I imagine it is not only for the advantages procurable; they must carry the accumulated burden of mistakes and try to correct them. We can meditate with advantage on these thoughts of $\mathrm{H}$. Multzer: "It is for the enterprise itself to establish itself as a community. There is a beginning to be made on this scale and it is up to the employers to make it. They are those who have monopolized the patrominy of the community to make it their own and it is they who must rectify this injustice. They are the ones, besides, who have assumed all the economic and social responsibilities of the individual and «liberal » enterprise; they are the ores who are responsible for the immense chaos that enterprise is wrecked; it is then they who must make the first steps towards a stable and just order where what remains valuable of their system could be integrated $\gg .^{3}$

I believe that your Bulletin could do a practical work if from time to time it would illustrate by certain practical applications already in use the principles and methods it advocates in order to show us how these would bring about order and even prosperity.

Quebec, September 15, 1949.

\section{Perreault}

(3) La propriété sans le vol, p. 131. 